\title{
Competition for water between beech seedlings and surrounding vegetation in different light and vegetation composition conditions
}

\author{
Lluis Coll ${ }^{\mathrm{a} *}$, Philippe Balandier ${ }^{\mathrm{a}}$, Catherine PiCon-Cochard ${ }^{\mathrm{b}}$, Bernard PrÉvosto ${ }^{\mathrm{a}}$, Thomas CurT ${ }^{\mathrm{a}}$ \\ ${ }^{a}$ CEMAGREF - U.R. DFCF, Applied Ecology of Woodlands Research Team, 24 avenue des Landais, BP 50085, 63172 Aubière Cedex, France \\ b INRA - U.R. Agronomie, 234 avenue du Brezet, 63039 Clermont-Ferrand, France
}

(Received 24 June 2002; accepted 10 February 2003)

\begin{abstract}
To gain a better understanding of beech growth requirements and assess the competition with the surrounding vegetation at two successional stages after agricultural land abandonment, we introduced two-year-old beech seedlings (i) in a recently abandoned meadow (one half weeded) and (ii) in an old meadow colonised by 25 -year-old natural Scots pine, with one part thinned to increase light availability at ground level. Beech seedlings presented significantly different stem diameter growth rates according to vegetation composition (grasses or dicotyledon species) and light availability for both successional stages. Grass species, which developed efficient strategies to extract soil water, competed strongly with beech seedling compared with dicotyledon species. Water competition led to a strong reduction of beech diameter growth. For a given vegetation composition, increasing light availability improved beech growth.
\end{abstract}

competition / Fagus sylvatica L. / understorey vegetation / grasses / root development / soil water content

Resume - Compétition pour l'eau entre de jeunes hêtres et la végétation environnante en fonction du niveau de lumière et de la composition de la végétation. Afin de mieux comprendre les conditions de croissance du hêtre et d'évaluer l'impact de la compétition par la végétation à deux stades de la succession végétale après abandon de terres agricoles, des plants de hêtre de deux ans ont été introduits : (i) dans une prairie récemment abandonnée (dont la moitié était désherbée) et (ii) dans une prairie abandonnée plus anciennement et colonisée par un boisement naturel de pin sylvestre de 25 ans (en partie éclairci pour obtenir différents niveaux d'éclairement au niveau du sol). Le taux de croissance en diamètre des jeunes plants de hêtre a été significativement différente en fonction de la composition de la végétation (graminées ou dicotylédones) et de l'éclairement. Les graminées ont la capacité de puiser l'eau très efficacement dans le sol en comparaison des dicotylédones, ce qui les rend très compétitives vis-à-vis des jeunes hêtres. Cette compétition a diminué la croissance en diamètre des jeunes plants. Par contre, à composition égale de la végétation, la croissance des plants de hêtre augmente avec le niveau d'éclairement.

compétition / Fagus sylvatica L. / végétation forestière / graminées / croissance racinaire / teneur en eau du sol

\section{INTRODUCTION}

Grazing abandonment in the "Chaîne des Puys", a volcanic massif located in the French Massif Central, has led to a natural afforestation of former agricultural land by pioneer trees such as Scots pine (Pinus sylvestris L.) [11, 24] and Silver birch (Betula pendula Roth.). Natural establishment of shade-tolerant broadleaved species such as beech (Fagus sylvatica L.) is observed beneath these pioneer stands [10]. Since beech forests in this area are assigned higher economic and ecological value than most of the current pine stands, beech restoration is of major interest for land managers.

The ecological requirements for beech establishment and development in forest stands have been studied in different site conditions [9, 20, 28, 29]. A light value of about $40 \%$ of incident radiation at ground level has generally been reported as optimal for beech seedling growth [23]. However, such a light level also favours thick ground vegetation [2] which may com- pete with the seedlings. The plant competitive ability differs from one species to another and little attention has been paid to the flora composition [8] and its consequences on resource availability for young seedlings [16, 21]. Generally, grasses (Graminaceae) are considered as the most harmful for young tree growth through competition for water or nutrients $[12,14]$ and other works have found differences in the competitive abilities of arborescent and non-arborescent species [4, 7].

The aim of this study was to characterise the below-ground competitive ability for water of two main classes of vegetation, grasses and dicotyledon species. We report also on the consequences of this competition on beech seedlings growth and settlement at two different successional stages after land abandonment, with different vegetation composition and light availability. Data could be used to adjust silvicultural operations to restore a beech forest from meadow at different stages after agricultural abandonment.

\footnotetext{
${ }^{*}$ Corresponding author: 1luis.coll@ cemagref.fr
} 
Table I. Main characteristics of the experimental plots.

\begin{tabular}{|c|c|c|c|c|c|}
\hline Treatment & Colonisation stage & $\begin{array}{l}\text { Pine density } \\
\left(\text { trees ha }{ }^{-1}\right)\end{array}$ & $\begin{array}{c}\text { Dominating } \\
\text { vegetation type }\end{array}$ & Main species & Transmitted PAR $(\%)^{\mathrm{b}}$ \\
\hline $\mathrm{M}+\mathrm{V}^{\mathrm{a}}$ & Old meadow & ---- & Grasses & $\begin{array}{c}\text { Arrhenaterum elatius } \\
\text { Agrostis capillaris } \\
\text { Festuca heterophylla } \\
\text { Holcus lanatus } \\
\text { Dactylis glomerata }\end{array}$ & 100 \\
\hline $\mathrm{M}-\mathrm{V}$ & Old meadow & ---- & Bare soil & ---- & 100 \\
\hline$P-V$ & 25-year-old Scots pine stand & 4012 & Bare soil & ---- & $9.9( \pm 1.4)$ \\
\hline$P+V$ & 25-year-old Scots pine stand & 496 & Dicotyledons & $\begin{array}{c}\text { Fragaria vesca } \\
\text { Moehringia trinervia } \\
\text { Doronicum austriacum } \\
\text { Rubus idaeus } \\
\text { Viola reichenbachiana }\end{array}$ & $41.4( \pm 4.5)$ \\
\hline
\end{tabular}

a See the text for meaning of the abbreviation.

b Transmitted PAR under canopy (but above the ground vegetation) estimated by the measurement of the transmitted global solar radiation corrected by a factor 0.9 (Sonohat, personal communication) $( \pm \mathrm{SD}, n=16)$.

\section{MATERIALS AND METHODS}

\subsection{Study area}

The experimental site is located in the southern part of the "Chaîne des Puys", a volcanic mid-elevation massif in the French Massif Central $\left(45^{\circ} 42^{\prime} \mathrm{N}, 2^{\circ} 59^{\prime} \mathrm{E}\right)$. The climate is mountainous with oceanic influences (annual rainfall $820 \mathrm{~mm}$, evenly spread over the year, annual mean temperature $7{ }^{\circ} \mathrm{C}$ ). Soils are well watered in the upper horizon but they present risks of rapid summer dryness since they have developed on a substrate of basaltic ash-fall deposits or lava blocks. In such soils, weathering leads to the formation of non-crystalline materials, especially allophone and $\mathrm{Al} / \mathrm{Fe}$ humus complex through a process of andosolisation [26]. These materials exhibit the typical morphological characteristics of andosols including dark colour, low density, microaggregated structure, loamy silt texture and thixotropic touch. They have a $\mathrm{pH}_{\text {water }}=6$ with a rich-organic upper horizon $(0-15 \mathrm{~cm})$. Soil analyses did not show evidence of mineral deficiency. Scoria are found at a depth of between 60 and $80 \mathrm{~cm}$. In such horizons, water capacity is very low.

\subsection{Experimental design}

The experiment was carried out at two successional stages in the process of woody colonisation after agricultural land abandonment: (i) in a recently abandoned meadow (M) and (ii) in an old meadow colonised by a natural dense 25 -year-old Scots pine stand (P). Two plots were set up in each stage (Tab. I): in the former meadow (M), one half of the area was periodically hand-weeded to maintain a bare soil and prevent installation of vegetation $\left(\mathrm{M}-\mathrm{V}, 75 \mathrm{~m}^{2}\right)$. The other half was left in natural conditions with no management $(M+V$, $75 \mathrm{~m}^{2}$ ). Plots were located close to each other in comparable site conditions. The dense Scots pine stand $(\mathrm{P})$ presented very low values of transmitted PAR under the pine canopy (9.9\%) and the understorey vegetation was very sparse $(\mathrm{P}-\mathrm{V}$ plot $)$. In order to increase light transmission to the soil and so allow the development of the understorey vegetation, a part of the stand was partially thinned in March 2000 to get $41.4 \%$ of transmitted PAR $(\mathrm{P}+\mathrm{V})$. Each plot $(\mathrm{P}-\mathrm{V}$ and $\mathrm{P}+\mathrm{V})$ had a surface of about $400 \mathrm{~m}^{2}(20 \times 20 \mathrm{~m})$.

The ground-vegetated plots $(\mathrm{M}+\mathrm{V}$ and $\mathrm{P}+\mathrm{V})$ differed markedly in plant species composition as recorded in July 2001 (i.e. two years after thinning in the $\mathrm{P}+\mathrm{V}$ plot). The meadow was strongly dominated by grasses: Arrhenatherum elatius (L.), Agrostis capillaris (L.), Festuca heterophylla (Lam.), Holcus lanatus (L.), Dactylis glomerata (L.) and Stellaria graminea (L.) while the thinned Scots pine plot (P + V) mainly supported dicotyledon species: Galium rotundifolium (L.), Fragaria vesca (L.), Moehringia trinervia (L.), Doronicum austriacum (Jacq.), Rubus idaeus (L.) and Viola reichenbachiana (Jord.).

Fifty two-year-old bare rooted beech seedlings $(52.8 \pm 7.9 \mathrm{~cm}$ height, $5.7 \pm 0.9 \mathrm{~mm}$ diameter) from a local tree nursery were planted in November 2000 in both meadow plots, and 100 beech seedlings were planted in the same period under the cover of each pine plot. Seedlings were arrayed systematically in rows of 10 plants spaced $1.2 \mathrm{~m}$ apart from each other, with $1.2 \mathrm{~m}$ distance between plants.

To prevent foraging by both small and large mammals, the plots were fenced.

\subsection{Growth of beech seedlings and ground vegetation}

Total stem height and stem basal diameter were measured at the beginning (May 2001) and at the end (October 2001) of the growing season on a sample of 50 beech seedlings in the middle of the pine plots $(\mathrm{P}-\mathrm{V}, \mathrm{P}+\mathrm{V})$ to avoid edge effects and to have the same sample size as the 50 seedlings planted on each meadow plot $(M-V, M+V)$.

From May to October 2001, root number, elongation and density of the ground vegetation were measured weekly using rhizotrons in the $\mathrm{P}+\mathrm{V}$ and $\mathrm{M}+\mathrm{V}$ plots. Rhizotrons allow sequential measurements to be made non-destructively on the same roots [19], but they can modify microclimatic soil conditions. Four rhizotrons per treatment were installed in March 2001 at $10 \mathrm{~cm}$ from a beech stem. Each rhizotron was composed of a glass ( $80 \mathrm{~cm}$ deep, $60 \mathrm{~cm}$ wide) driven vertically into the soil. New roots appearing on the glass were traced every week on a transparent polyester sheet. The sheets were scanned, and root elongation, root number and root density were calculated from the scan using WinRhizo ${ }^{\mathrm{TM}}$ software (Regent Instruments, Québec, Canada).

\subsection{Soil water content (SWC)}

Volume SWC was measured weekly with a TDR probe (Trime T3, IMKO, Ettlingen, Germany). Measurements were done in the first 0-20 $\mathrm{cm}$ where beech and ground vegetation root systems were mainly located. The TDR probe used was a tube-type device designed 
for measurements in permanent thin-walled plastic tubes. Thinwalled tubes were driven vertically into the soil with the help of an auger. Four tubes distributed in different parts of the plot were placed $20 \mathrm{~cm}$ away from beech seedlings in each treatment. For each tube and each date, the mean of three measurements made in three different directions was used for subsequent data analysis. To take into account possible differences in soil water content among plots at the beginning of the experiments, SWC was expressed in relative values with data referred to the first-day measurement (28 May).

\subsection{Tree water status}

Predawn leaf water potential $\left(\Psi_{\mathrm{p}}\right)$ and midday xylem water pressure $\left(\mathrm{P}_{\mathrm{x}}\right)$ of beech seedlings were measured on leaves with a pressure chamber [25] at three different dates during the growing season, two during drought periods (4 July and 1 August 2001) and the third in a wet period at the end of the vegetative season (28 August 2001).

Data were taken in all the treatments except for $\mathrm{M}+\mathrm{V}$, where beech seedlings soon presented signs of withering and leaf-shedding. Five different beech seedlings in each treatment were sampled for each date and three leaves per tree were collected. Leaves used for $\Psi_{p}$ measurements were collected at 04:00 am and measurements were conducted within one hour of collection, during which time they were kept in opaque plastic bags. The xylem water pressure $\left(\mathrm{P}_{\mathrm{x}}\right)$ at the base of the leaf was measured on leaves enclosed previously for at least $2 \mathrm{~h}$ in an air-proof aluminium foil bag [27].

\subsection{Light availability for seedlings}

The photosynthetically active radiation (PARt) transmitted by the ground vegetation, when present, was measured with a ceptometer (Decagon Devices, Pullman, WA, USA). PARt is the ratio of the PAR measured below the vegetation to the incident PAR (above the vegetation). The two PAR measurements were made at the same time using two sensors. Unidirectional measurements were made $10 \mathrm{~cm}$ away from the tree seedlings at three vertical levels: 10 and $20 \mathrm{~cm}$ under the apex of the seedlings and at soil level. At noon, ten seedlings per treatment were sampled and measurements were carried out weekly from May to October 2001 in the $\mathrm{M}+\mathrm{V}$ plot and during July 2001 in the $\mathrm{P}+\mathrm{V}$ plot.

\subsection{Data analysis}

To take into account the different initial sizes of the seedlings or ground vegetation in their above- and below-ground growth response, relative growth rate $\left(\mathrm{RGR}\right.$, day $\left.^{-1}\right)$ was used. RGR was calculated from:

$$
\mathrm{RGR}=1 / \mathrm{X}_{1} \times\left[\left(\mathrm{X}_{2}-\mathrm{X}_{1}\right) /\left(\mathrm{t}_{2}-\mathrm{t}_{1}\right)\right]
$$

where $t_{1}$ and $t_{2}$ are two measurement dates. For beech seedling stem diameter, $X_{1}$ is the basal diameter at $t_{1}$ and $X_{2}$ is the basal diameter at $t_{2}, t_{1}$ and $t_{2}$ being respectively the first and last days of measurements in the growing season.

For vegetation root elongation, $X_{1}$ is the root elongation at $t_{1}$ and $\mathrm{X}_{2}$ the root elongation at $\mathrm{t}_{2}, \mathrm{t}_{1}$ and $\mathrm{t}_{2}$ being two consecutive measurement dates.

Least significant distances (LSD) at $p<0.05$ were used to evaluate the differences between treatments using Statgraphics Plus 5.1 (Statistical Graphics Corp.) software.

\section{RESULTS}

\subsection{Beech seedling growth}

Beech seedlings presented significantly different stem basal diameter relative growth rates $\left(R_{G} R_{d}\right)$ between $M+V$ and $\mathrm{M}-\mathrm{V}$ and $\mathrm{P}+\mathrm{V}$ and $\mathrm{P}-\mathrm{V}$ respectively (Fig. 1). The thinned pine stand $(\mathrm{P}+\mathrm{V})$ and the weeded meadow $(\mathrm{M}-\mathrm{V})$ exhibited comparable and maximal beech $\mathrm{RGR}_{\mathrm{d}}$. In the dense pine stand $(\mathrm{P}-\mathrm{V}), \mathrm{RGR}_{\mathrm{d}}$ was halved compared with the thinned plot $(\mathrm{P}+\mathrm{V})$. The unweeded meadow plot $(\mathrm{M}+\mathrm{V})$ presented the lowest beech seedling $\mathrm{RGR}_{\mathrm{d}}$. At the end of the growing season, seedlings in the $\mathrm{M}+\mathrm{V}$ plot presented strong leaf shedding and evidences of stem dryness which conducted them to a mortality rate of about $90 \%$. No seedlings mortality was observed in the rest of modalities.

\subsection{Vegetation root development}

No significant differences in the total root length of the ground vegetation elongated during the entire growing season were found between treatments (Tab. II). The total number of roots elongated during the growing season was significantly higher for the upper 10-20 cm horizon in the meadow than in the pine plot. In both treatments, the greatest root development over the season was located in the upper horizon $(0-20 \mathrm{~cm})$,

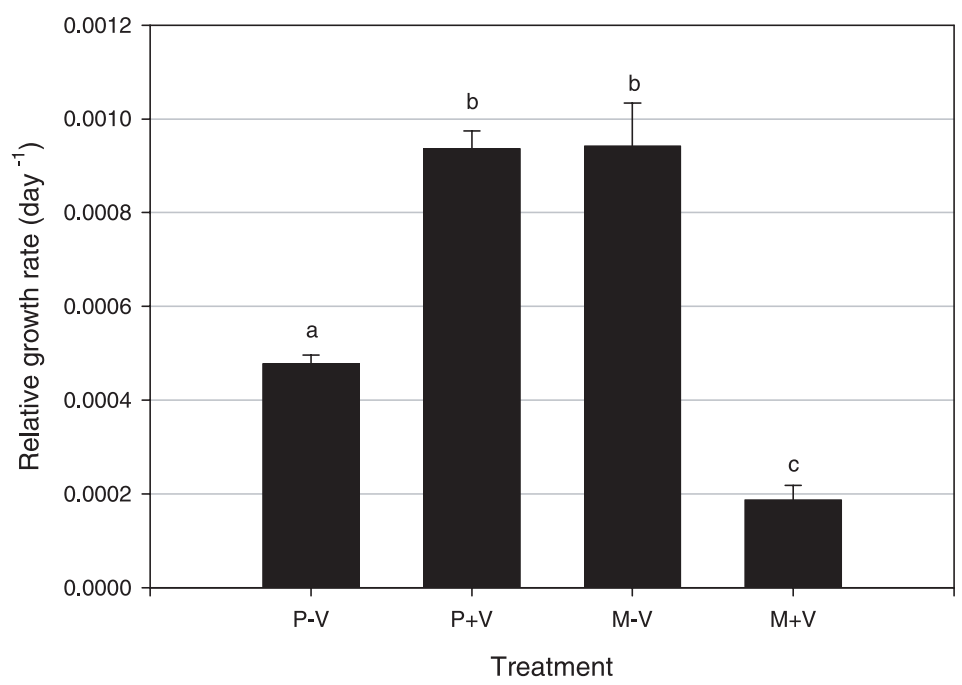

Figure 1. Stem basal diameter relative growth rate of beech seedling. The vertical bar denotes standard error of the mean $(n=50)$. Significant growth differences $(p<0.05)$ between treatments are indicated by different letters. 
Table II. Seasonal increment (from May to October 2001) of the ground vegetation root length and root number (mean \pm standard error) as the sum over the growing season of the increment values measured each week on the rhizotron glass. Values for each treatment and each horizon are the means of four rhizotrons. For each variable, significant differences between treatments are noted with different letters $(p<0.05)$.

\begin{tabular}{lrll}
\hline Parameter & Horizon & \multicolumn{2}{c}{ Treatment } \\
\cline { 3 - 4 } & & \multicolumn{1}{c}{$\mathrm{P}+\mathrm{V}$} & $\mathrm{M}+\mathrm{V}$ \\
\hline Total root length $(\mathrm{cm})$ & $0-10$ & $474( \pm 25)$ & $459( \pm 94)$ \\
& $10-20$ & $411( \pm 80)$ & $592( \pm 55)$ \\
& $20-30$ & $265( \pm 42)$ & $233( \pm 43)$ \\
Total root number & $30-40$ & $160( \pm 29)$ & $113( \pm 85)$ \\
& $0-10$ & $504( \pm 34)$ & $619( \pm 90)$ \\
& $10-20$ & $506( \pm 79)$ a & $929( \pm 139) \mathrm{b}$ \\
& $20-30$ & $321( \pm 40)$ & $309( \pm 51)$ \\
& $30-40$ & $180( \pm 42)$ & $120( \pm 83)$ \\
\hline
\end{tabular}

and root abundance decreased significantly with depth (Tab. II and Fig. 2). However, starting dates for the soil colonisation by vegetation roots were different between treatments. In the $\mathrm{M}+$ $\mathrm{V}$ plot, vegetation root growth started one month before the $\mathrm{P}+$ $\mathrm{V}$ plot (data not shown) and rapidly peaked in July (Fig. 2). In the $\mathrm{P}+\mathrm{V}$ plot, the soil was colonised later by the vegetation roots and more gradually during the growing season.

\subsection{Water availability}

\subsubsection{Soil water content (SWC)}

Relative SWC time course of the 0-20 cm deep layer varied according to rainfall events and treatment (Fig. 3). During the driest periods of the growing season, significant differences in SWC were found between the unweeded meadow $(\mathrm{M}+\mathrm{V})$ and the other treatments. Both pine treatments and the weeded meadow plot presented similar SWC values during the growing season except in the rainy periods (end of summer), when the SWC in the meadow plots was higher. At this time, ground vegetation in $\mathrm{M}+\mathrm{V}$ was withering and soil water extraction by the ground vegetation was probably minor compared with that due to the pine cover.

Obviously grass roots from the $\mathrm{M}+\mathrm{V}$ plots were able to grow better at low SWC values than roots of the pine understorey vegetation (Fig. 4). As this can result from a phenological effect (better root RGR at some periods), a general linear model was used to test any significant effect of the measurement day, the SWC and the interaction between both components (data not shown). Both the measurement date and the interaction between SWC and the measurement date had a significant effect: ground vegetation roots grew better during spring and the SWC was higher during this period. However, taking into account these effects, for a given date and a low value of SWC, the grass species roots still grew better than roots of dicotyledon species.

\subsubsection{Beech seedlings leaf water potentials}

Beech seedling predawn leaf water potential varied during the growing season and ranged between -0.17 and $-0.62 \mathrm{MPa}$ in the treatments sampled (Tab. III). Significant differences were found between the $\mathrm{P}-\mathrm{V}$ plot and the other treatments, but values did not indicate severe soil water deficits at any date.

The xylem water pressure $\left(\mathrm{P}_{\mathrm{X}}\right)$ data (Tab. III) showed that beech seedlings under the unthinned woody plot $(\mathrm{P}-\mathrm{V})$ did not suffer from water stress during the growing season, their values oscillating between -0.49 and $-0.87 \mathrm{MPa}$. However,

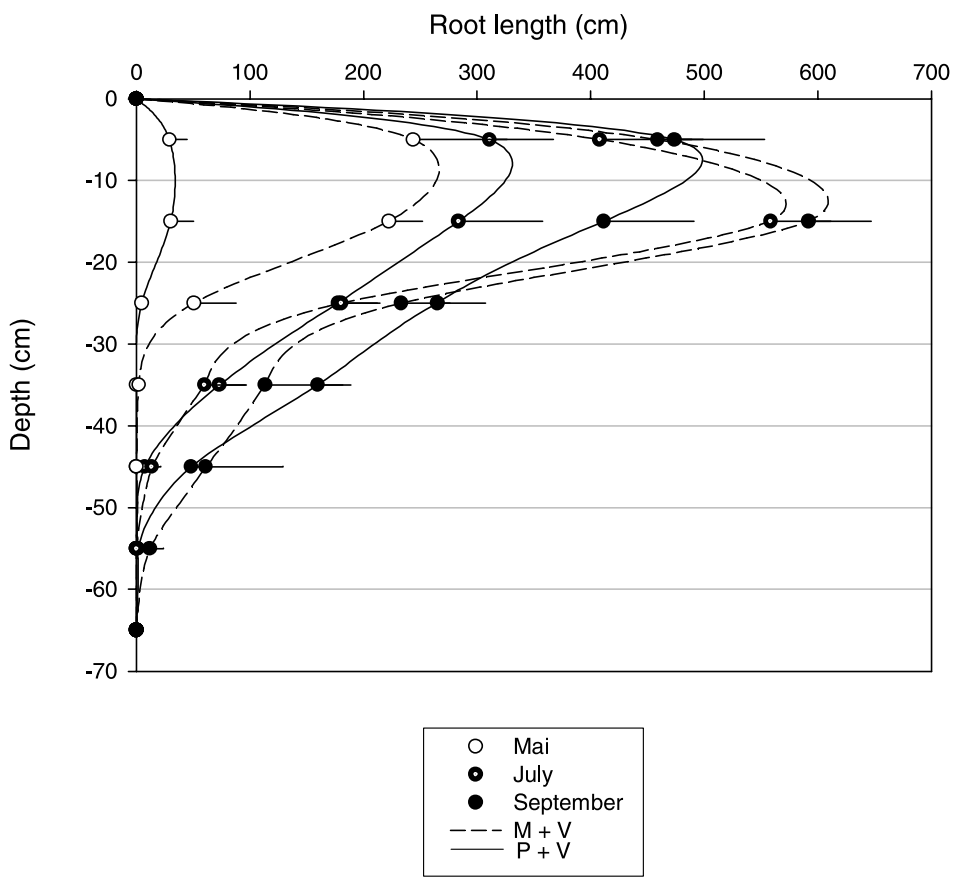

Figure 2. Ground vegetation root depth distribution on the soil profile at different dates for the $\mathrm{M}+\mathrm{V}$ (dash line) and the $\mathrm{P}+\mathrm{V}$ (solid line) plots. $\mathrm{X}$-axis is the cumulated root length $(\mathrm{cm}$, mean \pm standard error) and $\mathrm{Y}$-axis the soil depth $(\mathrm{cm})$. Values are represented at three different dates: end of May (white disk), end of July (dotted disk) and end of September (dark disk). 

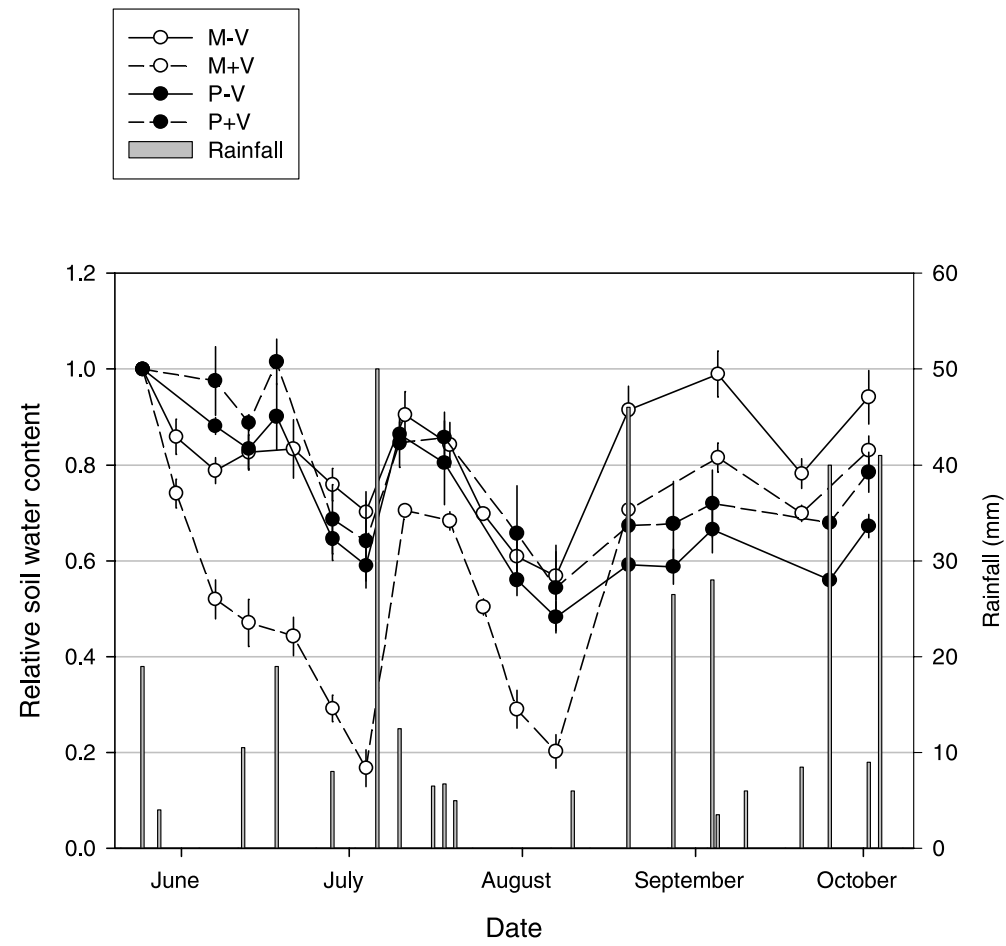

Figure 3. Time course of the relative soil water content (mean \pm standard error) (see M \& M section) as measured by TDR probe during the growing season 2001 for the upper $(0-20 \mathrm{~cm})$ soil horizon. Dark disks correspond to the Scots pine treatments $(\mathrm{P}-\mathrm{V}, \mathrm{P}+\mathrm{V})$ and white disks to meadow plots $(\mathrm{M}-\mathrm{V}, \mathrm{M}+\mathrm{V})$ with solid lines representing the bare-soil plots and dashed lines the plots with ground vegetation development. Grey columns represent rainfall on the meadow plot at weekly intervals.

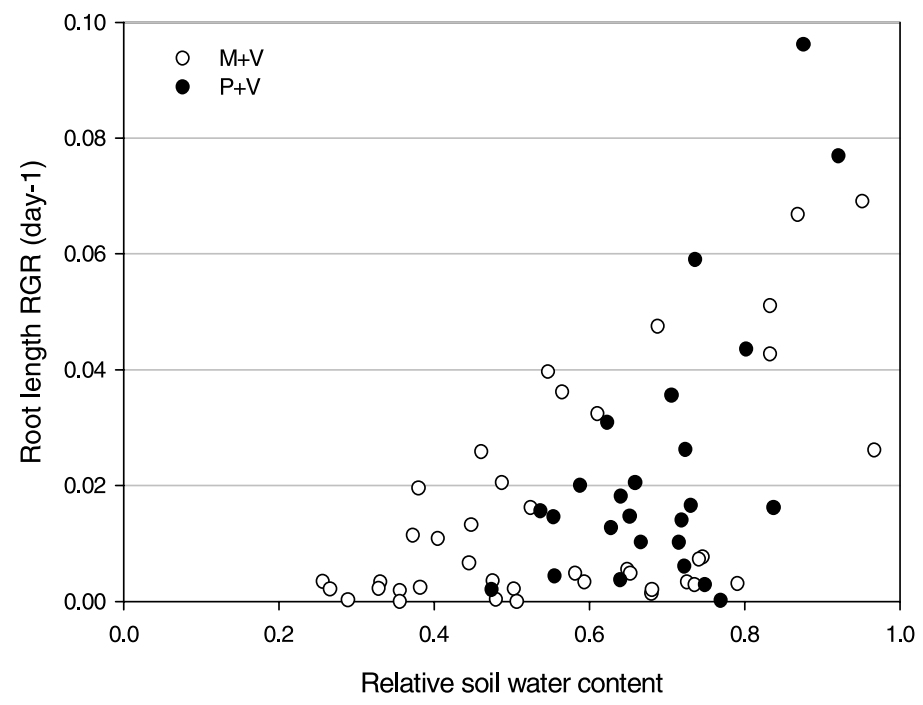

Figure 4. Ground vegetation root length RGR as a function of the relative soil water content for the upper horizon $(0-20 \mathrm{~cm})$. Each point corresponds to a rhizotron and a measurement week along the growing season 2001. Dark circles represent the vegetation from the pine treatment $(\mathrm{P}+\mathrm{V})$ and white circles the vegetation of the meadow $(\mathrm{M}+\mathrm{V})$ measurements of $\mathrm{P}_{\mathrm{X}}$ in $\mathrm{P}+\mathrm{V}$ and $\mathrm{M}-\mathrm{V}$ plots were significantly much more negative than in $\mathrm{P}-\mathrm{V}$, pointing to marked water constraint on beech seedlings. At the end of August, seedlings in the weeded meadow treatment $(\mathrm{M}-\mathrm{V})$ presented very negative $\mathrm{P}_{\mathrm{X}}(-2.7 \mathrm{MPa})$.

\subsection{Beech seedling light availability}

When light interception by ground vegetation was taken into account, differences were found between treatments
(Tab. IV). The PAR transmitted through the vegetation surrounding the beech seedlings was significantly lower in the $\mathrm{M}+\mathrm{V}$ plot than in the $\mathrm{P}+\mathrm{V}$ plot at the different plant height levels. However, the total PAR light interception by the ground vegetation was not very high; about $60 \%$ of the PAR was transmitted at $20 \mathrm{~cm}$ below the apex of the beech seedlings in both cases. Taking into account the PAR intercepted by the pine cover and the ground vegetation if present, beech seedling PAR availability ranged from 9.9, 39.4, 76.1 to $100 \%$ for respectively the $\mathrm{P}-\mathrm{V}, \mathrm{P}+\mathrm{V}, \mathrm{M}+\mathrm{V}$ and $\mathrm{M}-\mathrm{V}$ treatments. 
Table III. Predawn leaf water potential $\left(\Psi_{\mathrm{p}}\right)$ and midday xylem water pressure $\left(\mathrm{P}_{\mathrm{x}}\right)$ for beech seedlings measured at different dates during the growing season. Each value is the mean and standard error of five different seedlings, considering the $\Psi_{\mathrm{p}}$ and $\mathrm{P}_{\mathrm{x}}$ of one seedling as the mean of three leaves collected in different parts of the seedling crown. Significant differences between treatments $(p<0.05)$ for a given date are noted with different letters.

\begin{tabular}{lccc}
\hline Date & \multicolumn{4}{c}{ Treatments } \\
\cline { 2 - 4 } & $\mathrm{P}-\mathrm{V}$ & $\mathrm{P}+\mathrm{V}$ & $\mathrm{M}-\mathrm{V}$ \\
\hline \multirow{4}{*}{ Predawn water potential, MPa } \\
04 July & $-0.32( \pm 0.02) \mathrm{a}$ & $-0.62( \pm 0.01) \mathrm{b}$ & $-0.59( \pm 0.02) \mathrm{b}$ \\
28 August & $-0.17( \pm 0.02) \mathrm{a}$ & $-0.58( \pm 0.06) \mathrm{b}$ & $-0.49( \pm 0.01) \mathrm{b}$ \\
& \multicolumn{4}{c}{ Xylem water pressure, MPa } \\
26 June & $-0.87( \pm 0.09) \mathrm{a}$ & $-1.46( \pm 0.11) \mathrm{b}$ & $-1.84( \pm 0.05) \mathrm{c}$ \\
01 August & $-0.61( \pm 0.62) \mathrm{a}$ & $-1.4( \pm 0.04) \mathrm{b}$ & $-1.6( \pm 0.09) \mathrm{b}$ \\
28 August & $-0.49( \pm 0.06) \mathrm{a}$ & $-1.23( \pm 0.18) \mathrm{b}$ & $-2.7( \pm 0.09) \mathrm{c}$ \\
\hline
\end{tabular}

\section{DISCUSSION}

\subsection{Beech seedling growth and survival}

Marked differences in beech seedling development were found among the four treatments in this study. Beech diameter growth was significantly lower under the Scots pine forest $(\mathrm{P}-$ $\mathrm{V})$ than in the weeded meadow treatment $(\mathrm{M}-\mathrm{V})$. Obviously the lower transmitted radiation from the dense pine canopy prevented the development of understorey vegetation and also considerably limited beech seedling growth [15, 29].

In the thinned pine plot $(\mathrm{P}+\mathrm{V})$ seedlings diameter RGR was twice that in $\mathrm{P}-\mathrm{V}$. Light availability for the beech seedlings was considerably increased by the thinning, and the amount of PAR reaching the top of the seedlings rose from about $10 \%$ to $40 \%$. The ground vegetation also took advantage of this opening $[2,18]$, and a vegetation cover dominated by dicotyledon species developed. Despite the undergrowth, soil water content did not decrease in the plot. Water competition by the new ground vegetation was probably compensated by the increase of soil water content observed after thinning [20]. Since no significant differences in soil water availability were found between the pine plots (Fig. 3), and taking into account the fact that beech leaf nitrogen content was optimal for both pine treatments (data not shown), the increase in light availability presumably explains the better beech seedling development in the opened stand. The weeded meadow $(M-V)$ did not exhibit greater RGR values than the thinned plot despite fulllight conditions and absence of surrounding vegetation. This can be explained because full-light exposure also induces a high evaporation demand through a higher air water vapour deficit. The beech probably responded to the high transpiration rates by stomatal closure to prevent extensive developments of cavitation [6]. Therefore, $\mathrm{P}_{\mathrm{X}}$ was maintained above the cavitation threshold value [5] during the drought periods of the growing season. Nevertheless, beech $\mathrm{P}_{\mathrm{x}}$ values at the end of summer (28 August) sharply fell in $\mathrm{M}-\mathrm{V}$ compared with the other treatments and evidence of leaf withering was observed. Despite its acclimatation to contrasting sunlight conditions [5], beech stomatal regulation may not be sufficient to fully maintain xylem integrity, and partial cavitation may develop. Similar conclusions were recently drawn by Backes and Leuschner (2000) during occasional severe droughts in a mixed beech - sessile oak (Quercus petraea Matt.) forest.

Beech seedling growth was sharply reduced in the unweeded plot $(\mathrm{M}+\mathrm{V})$, and very few of the seedlings survived the full growing season. Water competition by the grass cover was clearly reflected in the soil water content time course of the plot (Fig. 3). Water deficit soon induced leaf shedding and was thus the main factor responsible for seedlings death. These results agree with many other studies that also report the negative effect of water competition by herbaceous vegetation on tree seedling survival and growth [12-14, 22].

Table IV. Transmitted PAR (\%) through the pine canopy, transmitted PAR through the ground vegetation at different depth in the vegetation (measured from the seedling apex) and calculated resulting PAR available for beech seedlings at different depth in the vegetation. Each value $(\%)$ is the mean and standard error of 10 trees. Significant differences $(p<0.05)$ between P $+\mathrm{V}$ and M $+\mathrm{V}$ ground vegetation transmitted PAR are indicated by different letters.

\begin{tabular}{|c|c|c|c|c|}
\hline & \multicolumn{4}{|c|}{ Treatment } \\
\hline & $\mathrm{P}-\mathrm{V}$ & $P+V$ & $\mathrm{M}-\mathrm{V}$ & $M+V$ \\
\hline Pine transmitted PAR & 9.9 & 41.4 & 100 & 100 \\
\hline \multicolumn{5}{|c|}{ Ground vegetation transmitted PAR } \\
\hline \multicolumn{5}{|c|}{ Distance below the beech apex $(\mathrm{cm})$} \\
\hline 10 & & $95.2( \pm 5.6) \mathrm{a}$ & & $76.1( \pm 11.4) \mathrm{d}$ \\
\hline 20 & & $81.2( \pm 13.6) b$ & & $58.3( \pm 10.3) \mathrm{e}$ \\
\hline Soil level & & $65.2( \pm 13.1) \mathrm{c}$ & & $25.8( \pm 9.4) \mathrm{f}$ \\
\hline \multicolumn{5}{|c|}{ Resulting PAR available for beech seedling } \\
\hline \multicolumn{5}{|c|}{ Distance below the beech apex $(\mathrm{cm})$} \\
\hline 10 & 9.9 & 39.4 & 100 & 76.1 \\
\hline 20 & & 33.6 & & 58.3 \\
\hline Soil level & & 27.0 & & 25.8 \\
\hline
\end{tabular}




\subsection{Competitive ability of ground vegetation according to species composition}

Two different types of vegetation were present in this study (Tab. I): grasses dominated the meadow plot $(\mathrm{M}+\mathrm{V})$, while dicotyledon species were dominant under the Scots pine canopy $(\mathrm{P}+\mathrm{V})$. Both vegetation types presented different aboveand below-ground development, strongly affecting their ability to compete for resources $[3,12]$. Although the cumulated root length was similar between both vegetation types, differences related to root dynamics and to root architecture were found. Grass roots colonisation of the soil profile started sooner and rapidly peaked in July. They mainly colonised the upper soil horizon $(0-20 \mathrm{~cm})$ and their abundance decreased sharply with depth. In contrast, the soil colonisation by the vegetation roots growing under the Scots pine stand was more progressive along the growing season. They were more evenly distributed in the soil profile (Tab. II and Fig. 2), being less present in the upper horizon but more abundant in the deeper soil layers.

These different patterns of vegetation root distribution show two different strategies of soil colonisation: (i) the grass strategy consisted in many short roots extended rapidly in the superficial soil horizon [17]; (ii) the pine understorey vegetation developed fewer but longer roots, able to reach deeper soil layers. Given that the root system of the three-year-old beech seedlings develops mainly in the upper soil layer [10], water competition by the ground vegetation would be considerably stronger in the meadow than in the thinned pine stand if the differences in soil colonisation between the two types of vegetation are taken into account. The strong competitiveness of grasses has been observed in many studies, particularly for water [14]. This may be related to the soil-colonising strategy of grass roots, but also to the capacity of grass roots to absorb water more efficiently than other plants. In this study, grass roots grew better at low soil water content levels than the pine understorey vegetation (Fig. 4). Therefore, during the drought periods, the adverse effect of grass on the tree water status may have been greater than that of the dicotyledon vegetation, owing to the higher capacity of grass to extract soil water. Hence the very low values of SWC in the unweeded meadow plot will probably always prevent beech set-up and growth in such conditions.

\subsection{Conclusion}

In this study, beech growth was compared at two stages of agricultural land abandonment: in a recently abandoned meadow and in an old meadow colonised by a naturally regenerated 25-year-old Scots pine stand. During the natural afforestation process, beech (as a late-successional species) does not settle directly in recently abandoned meadows. This study shows that beech seedling development was only possible in a weeded plot. In an unweeded plot, beech seedling survival was seriously compromised by competition for water by the grass cover, which had efficient strategies to extract soil water content even during water stress periods. However, seedling water status was also appreciably impaired in the weeded plot at the end of the growing season, probably due to a high water vapour deficit suffered by the seedlings during the severe drought periods.

In contrast, beech survival was not compromised under the Scots pine canopy, although we found an appreciable effect of shelterwood density: better beech growth under $40 \%$ PAR availability. The understorey vegetation resulting from thinning did not exert strong water competition, and beech was able to take advantage of the increased light availability.

Finally, in this study the effect of resources competition on beech development was focused on beech diameter growth. Further studies on beech acclimation to different environments in terms of physiological and morphological plasticity could be of interest to better characterise beech development at different stages of land abandonment.

Acknowledgements: We thank René Jouvie, Fabrice Landré and André Marquier for their valuable technical help in the field. This research was funded by the Auvergne Region and by the FNADT program.

\section{REFERENCES}

[1] Backes K., Leuschner C., Leaf water relations of competitive Fagus sylvatica and Quercus petraea trees during 4 years differing in soil drought, Can. J. For. Res. 30 (2000) 335-346.

[2] Balandier P., Pauwels D., La lumière, outil sylvicole pour favoriser la diversité végétale ou la gestion cynégétique des peuplements de mélèze (Larix sp.), Forêt Wallone 61 (2002) 9-13.

[3] Casper B.B., Jackson R.B., Plant competition underground, Annu. Rev. Ecol. Syst. 28 (1997) 545-570.

[4] Carter G.A., Miller J.H., Davis D.E., Patterson R.M., Effect of vegetative competition on the moisture and nutrient status of loblolly pine, Can. J. For. Res. 14 (1983) 1-9.

[5] Cochard H., Lemoine D., Dreyer E., The effects of acclimation to sunlight on the xylem vulnerability to embolism in Fagus sylvatica L., Plant Cell Environ. 22 (1999) 101-108.

[6] Cochard H., Coll L., Le Roux X., Améglio T., Unraveling the effects of plant hydraulics on stomatal closure during water stress in walnut, Plant Physiol. 128 (2002) 282-290.

[7] Cole E.C., Newton M., Fifth-year responses of Douglas-fir to crowding and nonconiferous competition, Can. J. For. Res. 17 (1987) 181-186.

[8] Collet C., Frochot H., Guehl J.M., Growth dynamics and water uptake of two forest grasses differing in their growth strategy and potentially competing with forest seedlings, Can. J. Bot. 74 (1996) $1555-1561$.

[9] Collet C., Lanter O., Pardos M., Effects of canopy opening on height and diameter growth in naturally regenerated beech seedlings, Ann. For. Sci. 58 (2001) 127-134.

[10] Curt T., Prévosto B., Root biomass and rooting profile of naturally regenerated beech in mid-elevation Scots pine woodlands, Plant Ecol. 167 (2003) 269-282.

[11] Curt T., Prévosto B., Klescewski M., Lepart J., Post-grazing Scots pine colonization of mid-elevation heathlands: population structure, impact on vegetation composition and diversity, Ann. For. Sci. 60 (2003) 711-724.

[12] Davies R.J., Trees and weeds. Weed control for successful tree establishment, in: Forestry commission-Handbook, HMSO Publications, London, 1987, pp. 2-36.

[13] Davies M.A., Wrage K.J., Reich P.B., Tjoelker M.G., Schaeffer T., Muermann C., Survival, growth, and photosynthesis of tree 
seedlings competing with herbaceous vegetation along a waterlight-nitrogen gradient, Plant Ecol. 145 (1999) 341-350.

[14] Frochot H., Picard J.F., Dreyfus P., La végétation herbacée obstacle aux plantations, Rev. For. Fr. 37 (1986) 271-279.

[15] Gemmel P., Nilsson U., Welander T., Development of oak and beech seedlings planted under varying shelterwood densities and with different site preparation methods in southern Sweden, New For. 12 (1996) 141-161.

[16] Harmer R., Robertson M., Seedling root growth of six broadleaved tree species grown in competition with grass under irrigated nursery conditions, Ann. For. Sci. 60 (2003) 601-608.

[17] Jackson R.B., Canadell J., Ehleringer J.R., Mooney H.A., Sala O.E., Schulze E.D., A global analysis of root distributions for terrestrial biomes, Oecologia 108 (1996) 389-411.

[18] Kolb T.E., Steiner K.C., Growth and biomass partitioning of northern red oak and yellow poplar seedlings: effect of shading and grass root competition, For. Sci. 36 (1990) 34-44.

[19] Lopez B., Sabaté S., Gracia C., An inflatable minirhizotron system for stony soils, Plant Soil 179 (1996) 255-260.

[20] Madsen P., Larsen J.B., Natural regeneration of beech (Fagus sylvatica $\mathrm{L}$.) with respect to canopy density, soil moisture and soil carbon content, For. Ecol. Manage. 97 (1997) 95-105.

[21] Morris L.A., Moss S.A., Garbett W.S., Competitive interference between selected herbaceous and woody plants and Pinus taeda L. during two growing seasons following planting, For. Sci. 39 (1993) 166-187.

[22] Nambiar E.K.S., Sands R., Competition for water and nutrients in forests, Can. J. For. Res. 23 (1993) 1955-1968.

[23] Oswald H., Conditions de germination des faînes, de survie et de croissance des semis, in: Teissieur du Cros E. (Ed.), Le hêtre, INRA, Paris, 1981, pp. 221-239.

[24] Prévosto B., Curt T., Gueugnot J., Coquillard P., Modeling midelevation Scots pine growth on a volcanic substrate, For. Ecol. Manage. 131 (2000) 223-237.

[25] Scholander P.F., Hammel H.T., Bradstreet E.D., Hemmingsen E.A., Sap pressure in vascular plants, Science 148 (1965) 339-346.

[26] Shoji S., Nanzyo M., Dahlgren R., Volcanic ash soils, Elsevier, Amsterdam, 1993.

[27] Turner N.C., Long M.J., Errors arising from rapid water loss in the measurement of leaf water potential by the pressure chamber technique, Aust. J. Plant. Physiol. 7 (1980) 527-537.

[28] Van Hess A.F.M., Growth and morphology of pedunculate oak (Quercus robur L.) and beech (Fagus sylvatica L.) seedlings in relation to shading and drought, Ann. Sci. For. 54 (1997) 9-18.

[29] Welander T., Ottosson B., The influence of shading on growth and morphology in seedlings of Quercus robur L. and Fagus sylvatica L., For. Ecol. Manage. 107 (1998) 117-126. 